\title{
Association of a missense mutation in the bovine leptin gene with carcass fat content and leptin mRNA levels
}

\author{
Fiona C. Buchanan ${ }^{\mathrm{a}, *}$, Carolyn J. Fitzsimmons ${ }^{\mathrm{b}}$, \\ Andrew G. Van Kessel ${ }^{a}$, Tracey D. Thue ${ }^{a}$, \\ Dianne C. Winkelman-Sim ${ }^{\mathrm{a}}$, Sheila M. Schmutz ${ }^{\mathrm{a}}$ \\ ${ }^{a}$ Department of Animal and Poultry Science, 51 Campus Drive, \\ University of Saskatchewan, Saskatoon, S7N 5A8, Canada \\ ${ }^{b}$ Department of Animal Science, 2255 Kildee Hall, \\ Iowa State University, Ames, 50011, USA
}

(Received 16 May 2001; accepted 24 September 2001)

\begin{abstract}
Previously, we have shown that alleles of the BM1500 microsatellite, located $3.6 \mathrm{~kb}$ downstream of the leptin gene in cattle, were associated with carcass fat measures in a population of 154 unrelated beef bulls. Subsequently, a cytosine (C) to thymine (T) transition that encoded an amino acid change of an arginine to a cysteine was identified in exon 2 of the leptin gene. A PCR-RFLP was designed and allele frequencies in four beef breeds were correlated with levels of carcass fat. The $\mathrm{T}$ allele was associated with fatter carcasses and the $\mathrm{C}$ allele with leaner carcasses. The frequencies of the SNP alleles among breeds indicated that British breeds have a higher frequency of the $\mathrm{T}$ allele whereas the continental breeds have a higher occurrence of the $\mathrm{C}$ allele. A ribonuclease protection assay was developed to quantify leptin mRNA in a separate group of animals selected by genotype. Animals homozygous for thymine expressed higher levels of leptin mRNA. This may suggest that the T allele, which adds an extra cysteine to the protein, imparts a partial loss of biological function and hence could be the causative mutation.
\end{abstract}

\section{leptin / cattle / obese / fat / marbling}

\section{INTRODUCTION}

Leptin is the hormone product of the obese gene that acts on central and peripheral tissues to modulate appetite and energy metabolism [16]. In ruminant animals, as in other species studied, leptin is secreted predominantly by adipocytes [5,18]. Plasma leptin levels in cattle and sheep increase linearly with increased body fat mass and with increased energy balance $[2,3,6]$. Systemic

\footnotetext{
* Correspondence and reprints
}

E-mail: buchanan@sask.usask.ca 
or central administration of leptin reduces feed intake in rodents, chickens, pigs, and sheep $[1,13,15,24]$ and while data from livestock species remains sparse, leptin appears to be an important component of a feedback loop involving key metabolic regulators including insulin, glucocorticoids and the sympathetic nervous system [16]. Finally, in vitro studies suggest that leptin can directly modulate energy metabolism in peripheral tissues and may antagonize insulin activities in adipose [21] and muscle [22]. These physiological properties support leptin as a strong candidate gene for evaluation of genetic polymorphisms that could affect carcass fat content in cattle.

In a previous study conducted by our group we uncovered an association between the $B M 1500$ microsatellite and carcass fat levels in beef cattle [7]. This microsatellite is located approximately $3.6 \mathrm{~kb}$ downstream of the leptin gene stop codon on bovine chromosome $4[29,30]$. We decided to investigate the leptin gene itself for polymorphisms linked to the $B M 1500$ microsatellite and to carcass fat content, and to investigate further any promising polymorphisms by measuring mRNA levels in adipose tissue.

\section{MATERIALS AND METHODS}

\subsection{Cattle}

\subsubsection{Genotype correlation with carcass data}

Six animals of various breeds were selected from a population of 154 unrelated (no common sire or dam) beef bulls for which carcass data was available [7] to screen for polymorphisms in the leptin gene. Three bulls (one Angus, one Hereford and one Charolais) were selected to represent a fat phenotype. These animals were also homozygous for the BM1500 microsatellite allele associated with high carcass fat [7]. The other three bulls (one Angus and two Charolais) represented a lean phenotype and were homozygous for the BM1500 microsatellite allele associated with lean carcass measurements. The 154 bulls were genotyped with the resulting PCR-RFLP. There were 60 Angus, 55 Charolais, 22 Hereford and 17 Simmental that were all raised at the Beef Research Unit at the University of Saskatchewan [7].

\subsubsection{Genotype correlation with leptin expression}

The PCR-RFLP was also used to select genotypically 34 unrelated crossbred animals (17 TT and $17 \mathrm{CC}$ ), 16 unrelated purebred Simmentals (8 TT and $8 \mathrm{CC}$ ) and 15 animals from the Canadian Beef Reference Herd [27] (8 TT and 7 CC). Fat samples were collected at the time of slaughter so that leptin mRNA levels could be determined. 


\subsection{Sequencing}

The genomic bovine leptin sequence, which consists of three exons, was obtained from GenBank (Accession \# U50365). Primers were designed to flank exons 2 and 3 of the gene. Exon 1 was not sequenced because it is a non-coding exon. In each bull exons 2 and 3 were amplified by PCR, and the products were used for direct sequencing. A single reaction $(20 \mu \mathrm{L})$ contained the following constituents: 10X PCR buffer, $60 \mu \mathrm{g} \cdot \mathrm{mL}^{-1} \mathrm{BSA}, 2 \mathrm{mM} \mathrm{MgCl}{ }_{2}$, $200 \mu \mathrm{M}$ dNTPs, 10 pmoles of forward and reverse primers, $0.6 \mathrm{U}$ Taq DNA polymerase (Gibco BRL), and 50-100 ng of genomic DNA. The thermalcycler used was a Stratagene ${ }^{\circledR}$ Robocycler ${ }^{\circledR} 40$. The program to amplify leptin exon 2 consisted of $4 \mathrm{~min}$ at $94^{\circ} \mathrm{C}$, followed by a cycle that ran 30 times: $94^{\circ} \mathrm{C}$ for $45 \mathrm{~s}, 56^{\circ} \mathrm{C}$ for $55 \mathrm{~s}$, and $72^{\circ} \mathrm{C}$ for $45 \mathrm{~s}$. The PCR program used to amplify exon 3 was identical to the one used for exon 2 except that the annealing temperature was $60^{\circ} \mathrm{C}$. Both programs ended with a final extension of $72^{\circ} \mathrm{C}$ for $4 \mathrm{~min}$.

PCR products were purified for sequencing using the QIAGEN $^{\circledR}$ QIAquick $^{\mathrm{TM}}$ PCR purification kit, or the QIAquick ${ }^{\mathrm{TM}}$ Gel extraction kit before being sent for sequencing to the Canadian National Research Council Plant Biotechnology Institute, Saskatoon, SK. Forward and reverse sequences of leptin exons 2 and 3 were generated for each animal on an Applied Biosystems 373 DNA Sequencer. These sequences were then comparatively analyzed for polymorphisms using MacVector ${ }^{\mathrm{TM}}$ 5.0.2 DNA sequence analysis software.

\subsection{Purposeful mismatch PCR-RFLP}

The SNP in exon 2 could be distinguished by digestion with the restriction endonuclease AciI, however this enzyme is inhibited by PCR reagents which required purification prior to digestion [8]. Consequently, we introduced a purposeful mismatch in the reverse primer that presented a Kpn2I recognition site. New forward and reverse primers were

\section{(5' ATGCGCTGTGGACCCCTGTATC 3')}

and

\section{(5' TGGTGTCATCCTGGACCTTCC 3')}

respectively. A single reaction ( $20 \mu \mathrm{L})$ contained the following constituents: 10X PCR buffer, $1.5 \mathrm{mM} \mathrm{MgCl}_{2}, 200 \mu \mathrm{M}$ dNTPs, 10 pmoles of forward and reverse primers, $1 \mathrm{U}$ Taq DNA polymerase (Gibco BRL), and 50-100 ng of genomic DNA. The amplification program consisted of an initial denaturation at $94{ }^{\circ} \mathrm{C}$ for $2 \mathrm{~min}$, followed by a cycle that ran 35 times: $94{ }^{\circ} \mathrm{C}$ for $45 \mathrm{~s}, 52^{\circ} \mathrm{C}$ for $45 \mathrm{~s}$, and $72{ }^{\circ} \mathrm{C}$ for $55 \mathrm{~s}$. A final extension of $72{ }^{\circ} \mathrm{C}$ was maintained for 3 min. 
A single digestion reaction consisted of $15 \mu \mathrm{L}$ of PCR product, $2 \mathrm{U}$ of Kpn2I (MBI Fermentas), 10X $\mathrm{Y}^{+} /$Tango buffer, and $4 \mathrm{mM}$ of spermidine. The final reaction volume of $20 \mu \mathrm{L}$ was incubated at $55^{\circ} \mathrm{C}$ for $1 \mathrm{~h}$. The fragments were separated on a $3 \%$ agarose gel by electrophoresis.

\subsection{RNA extraction and ribonuclease protection assay (RPA)}

Adipose tissue was collected at slaughter and the total RNA was extracted using TRIzol reagent (Life Technologies). Transcribed antisense RNA probes were prepared with the Maxiscript ${ }^{\mathrm{TM}}$ in vitro transcription kit (Ambion) and were gel purified. The leptin ( $L E P$ ) probe was 253 bp (Genbank Accession \# AB003143 corresponding to bp 1-253) and the glyceraldehyde phosphate dehydrogenase $(G A P D H)$ probe was 325 bp [14]. GAPDH is constitutively expressed [11] and hence was included to ensure homogenous loading of lanes. The RPA was performed using a commercial kit (RPA III ${ }^{\mathrm{TM}}$, Ambion). Ten micrograms of total RNA was hybridized with $80000 \mathrm{cpm}{ }^{32} \mathrm{P}$-labeled $L E P$ and $3200 \mathrm{cpm} G A P D H$ probes at $42^{\circ} \mathrm{C}$ overnight. This was then digested for $30 \mathrm{~min}$ at $37^{\circ} \mathrm{C}$ with a 1:50 dilution of $\mathrm{T}_{1} \mathrm{RNase}$. The protected fragments were resolved on a $6 \%$ denaturing polyacrylamide gel. Densitometry with HS1D Advanced American Biotechnology software (Biomed Instruments) was used to analyse autoradiographic bands to obtain the $L E P / G A P D H$ ratios.

\subsection{Statistical analysis}

Allele frequencies between breeds were compared using chi-square analysis. The effects of genotype at the SNP on average fat, grade fat, marbling, and percent rib fat were determined by analysis of variance using the model:

$$
Y_{i j k}=u+B R_{i}+G E N O(B R)_{j(i)}+e_{i j k}
$$

where:

$Y_{i j k} \quad$ is the trait measured on the individual bull,

$u \quad$ is the overall mean for the trait,

$B R_{i} \quad$ is the effect of the $i$-th breed $(i=1,2,3,4)$,

$\operatorname{GENO}(B R)_{j(i)}$ is the effect of the $j$-th SNP genotype within the $i$-th breed $(j=1,2,3)$, and

$e_{i j k} \quad$ is the residual error.

The results from the RPA were analyzed using a one-way ANOVA. 
41- ATG CGC TGT GGA CCC CTG TAT CGA TTC CTG TGG CTT TGG CCC

36- ATG CGC TGT GGA CCC CTG TAT CGA TTC CTG TGG CTT TGG CCC

41- TAT CTG TCT TAC GTG GAG GCT GTG CCC ATC CGC AAG GTC CAG

$\operatorname{Arg}$

36- TAT CTG TCT TAC GTG GAG GCT GTG CCC ATC TGC AAG GTC CAG

Cys

41- GAT GAC ACC AAA ACC CTC ATC AAG ACA ATt GTC ACC AGG

36- GAT GAC ACC AAA ACC CTC ATC AAG ACA ATT GTC ACC AGG

41- ATC AAT GAC ATC TCA CAC ACG

36- ATC AAT GAC ATC TCA CAC ACG

Figure 1. Entire leptin exon 2 sequence from bulls \#41 (lean), and \#36 (fat). The signal sequence is boxed. The cytosine to thymine SNP is highlighted in bold letters. Amino acid change imparted by the SNP is also shown.

\section{RESULTS}

Among the six bulls sequenced, one SNP was found in leptin exon 2 and five SNPs were found in exon 3. All of these SNPs except for one located $73 \mathrm{bp}$ from the start of exon 2, and another located $95 \mathrm{bp}$ from the start of exon 3, were at silent codon positions and did not affect the encoded amino acid. The polymorphism located in exon 2 is a cytosine to thymine transition and is located in the first base position of the 25 th codon. It changes the commonly reported amino acid at that position, an arginine (encoded by the $\mathrm{C}$ allele), into a cysteine (encoded by the T allele; Accession \# AF120500, submitted Jan. 15, 1999; Fig. 1). All three bulls selected for sequencing based on high fat phenotype were homozygous for thymine and therefore a cysteine amino acid in the leptin molecule at this position. The three lean bulls were homozygous for cytosine and consequently arginine. In the mature leptin protein, this amino acid change is located fourth from the $\mathrm{N}$-terminus of the molecule because a signal peptide (1st to 21st amino acids) is cleaved off before leptin is excreted from adipose tissue (Accession \# AB003143) [33].

The other SNP located in exon 3 also encoded an amino acid change; alanine was substituted with valine. This SNP was not analyzed further because it 


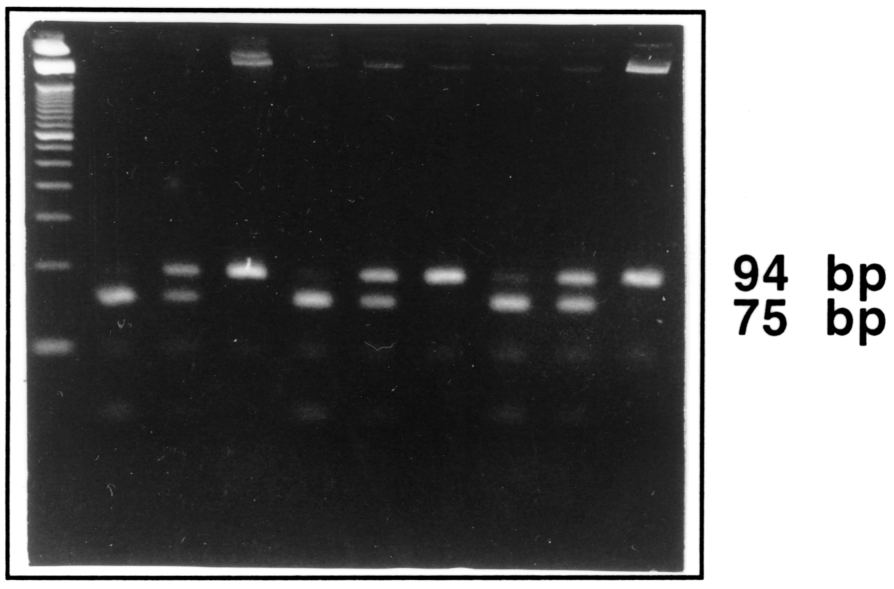

Figure 2. A $3 \%$ agarose gel displaying a $K p n 2 \mathrm{I}$ restriction digest on an amplified portion of bovine leptin exon 2. Lane 1, 50 bp ladder (Gibco BRL); lanes 2, 5, and 8 are CC; lanes 3, 6, and 9 are CT; and lanes 4, 7 and 10 are TT.

was not consistently different between the sequenced lean and fat bulls, and because alanine and valine are both amino acids with similar non-polar aliphatic R-groups, which represents a conserved substitution. The cysteine/arginine change in exon 2 is a non-conserved substitution and is more likely to alter the functioning of the leptin hormone.

The SNP in exon 2 could be distinguished by digestion with the restriction enzyme Kpn2I following amplification with a purposeful mismatch primer. The $\mathrm{C}$ allele was cleaved into two fragments of 75 and $19 \mathrm{bp}$, while the $\mathrm{T}$ allele remained uncut at 94 bp (Fig. 2). Mendelian inheritance of the SNP was confirmed in an independent cattle family (data not shown). The PCRRFLP was performed on the population of 154 unrelated beef bulls for which carcass data were available. Chi-square analysis detected a difference in allele frequencies across breeds $\left(\chi^{2}=9.106, P=0.03\right.$; Tab. I). The frequency of the $\mathrm{T}$ allele was higher in Angus than Charolais $(P=0.01)$ and Simmentals $(P=0.04)$. The effects of the SNP genotypes on carcass fat measurements were analyzed by analysis of variance with the fixed effect of breed included in the model. Both average fat and grade fat are significantly affected by genotype ( $P=0.023$ and $P=0.013$ respectively).

Upon optimization of the RPA there was a linear response in band density with the increasing amount of total RNA (Fig. 3). Animals homozygous for the $\mathrm{T}$ allele produced more leptin mRNA than animals homozygous for the $\mathrm{C}$ allele (Fig. 4). The response was significant in unrelated purebred $(P=0.05)$ and crossbred steers $(P=0.02)$ while a trend was noted in the animals selected from the Canadian Beef Reference Herd. 
Table I. Allele frequencies of the leptin exon 2 SNP for the test population of beef bulls.

\begin{tabular}{lccc}
\hline Breed & $n$ & $\mathrm{C}$ & $\mathrm{T}$ \\
\hline Angus & 60 & $0.42^{\mathrm{a}}$ & 0.58 \\
Charolais & 55 & $0.66^{\mathrm{b}}$ & 0.34 \\
Hereford & 22 & $0.45^{\mathrm{ab}}$ & 0.55 \\
Simmental & 17 & $0.68^{\mathrm{b}}$ & 0.32 \\
\hline Total & 154 & 0.54 & 0.46 \\
\hline
\end{tabular}

a,b Values with different superscripts are significantly different $(P<0.05)$.

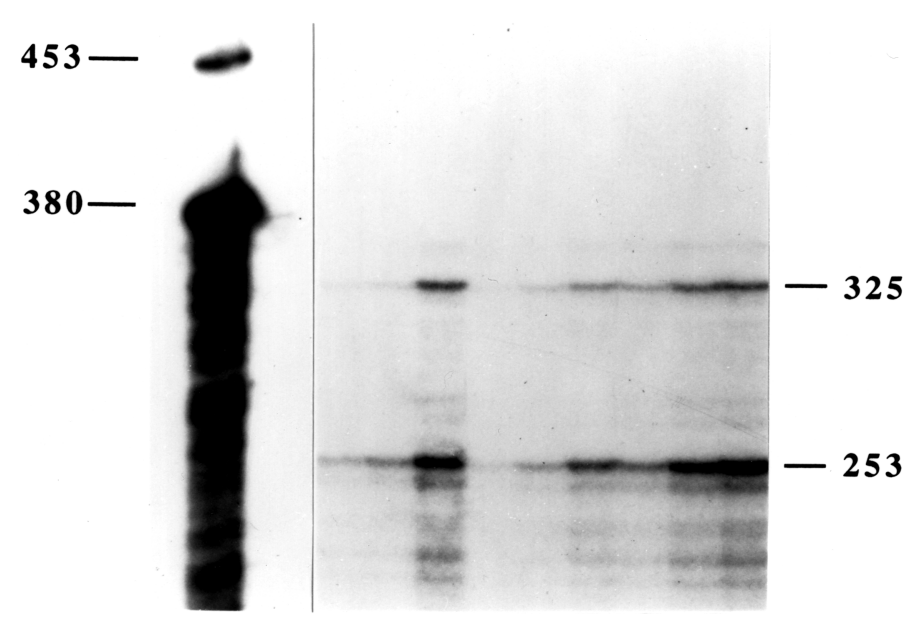

Figure 3. Dose response to increasing amounts of total RNA. Lane 1 is the positive control - yeast RNA without digestion - full-length GAPDH is $453 \mathrm{bp}$ and full-length leptin is 380 bps. Lane 2 is the negative control - digested yeast RNA. Lanes 3-5, 6-8, and 9-11 represent three individuals loaded with 5, 10 and $20 \mu \mathrm{g}$ of total RNA (253 bp bovine leptin and 325 bp bovine GAPDH riboprobes were used).

\section{DISCUSSION}

Several polymorphisms within the leptin gene in cattle have been described. A microsatellite has been located in the $5^{\prime}$ UTR of the leptin gene [32] and nine SNPs have been discovered in intron 2 of the bovine leptin gene [20,23]. The polymorphisms reported in this study that change the amino acid in exons 2 (Arg/Cys) and 3 (Ala/Val) have been confirmed by Konfortov et al. [19], who also report several other intronic polymorphisms in a diverse panel of cattle breeds. Haegeman et al. [12] also report the alanine to valine substitution as well as an amino acid change from Glu to Arg in exon 3. Only two of the 


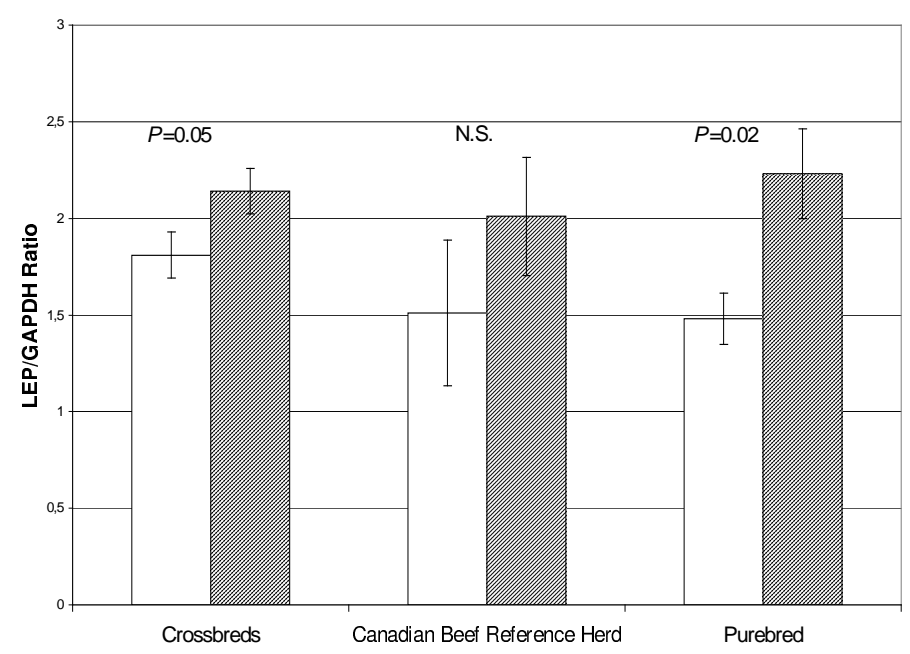

Figure 4. Optical density of the ratio of leptin $(L E P)$ to GAPDH protected fragments in three groups of genotypically selected animals. Animals homozygous for the $\mathrm{C}$ allele are depicted by open boxes while TT homozygotes are shown as hatched boxes.

polymorphisms listed above result in amino acid substitutions that are nonconservative Arg/Cys and Glu/Arg. The former was identified in this study between animals selected from extremes in fat phenotype and the latter was found from sequencing two unrelated Belgian Blue crossbred animals [12].

We found significant associations between the SNP genotype in exon two and carcass fat levels in cattle. Regression analysis (not shown) revealed that the thymine allele was associated with fatter carcasses and the $\mathrm{C}$ allele with leaner carcasses. This is similar to our finding with the BM1500 microsatellite where two of the four alleles were associated with higher or lower body fat content [7]. While this could be due to linkage disequilibrium, as the microsatellite is only $3.6 \mathrm{~kb}$ away, the SNP observed in exon three was not consistent between phenotypes, which suggests that our SNP in exon 2 could be the causative mutation.

In support of the suggestion that the exon 2 SNP (Arg/Cys) may be the causative mutation, leptin mRNA expression was higher in cattle homozygous for the thymine $(\mathrm{T})$ allele. An increase in leptin expression could reflect a feedback response in compensation for reduced biological function - several researchers have reported this same substitution having major biological effect. For example, Inaba et al. [17] demonstrated that the Arg104Cys in the vassopressin type 2 receptor was responsible for diminished binding capacity resulting in decreased function that subsequently caused congenital nephrogenic diabetes insipidus in a patient. On substitution of the arginine for serine instead of cysteine, binding capacity and function returned to wild-type levels indicating the importance of the cysteine sulfhydryl group. Ribba et al. [25] 
showed that the Arg552Cys mutation in the von Willebrand factor resulted in abnormal folding and loss of function resulting in type 2A-like phenotype of von Willebrand disease. The Arg615Cys substitution in ryanodine receptors increases calcium release in malignant hyperthermia-susceptible pigs [9].

The frequencies of the SNP alleles within breeds also supports an association with the exon 2 SNP and carcass fat content. The British breeds have a higher frequency of the thymine allele whereas the continental breeds have a higher preponderance of the $\mathrm{C}$ allele. British breeds (Angus and Hereford) are characterized by their early maturity as compared to continental breeds (Charolais and Simmental), giving them the capacity to carry more fat at a younger age [10].

We hypothesized that the amino acid change from arginine to cysteine is imparting a functional difference to the leptin molecule. One explanation may be that the cysteine's presence in the A-helix of the leptin molecule may disrupt the binding of leptin to its receptor. The leptin receptor contains a conserved trough typical of haemopoietic cytokine receptors, into which the A and D helixes of haemopoietic cytokines dock [28]. Therefore a change between two very different amino acids such as arginine and cysteine at this location may have some detrimental effect on this process. Another explanation for a functional change may be that the presence of another unpaired cysteine in the leptin molecule could destabilize the disulfide bridge found between the 2 existing cysteines [26]. This disulfide bridge has been shown to be critical for biological function [26,33]. Also, the location of the bridge as determined through x-ray crystallography is in close proximity to the N-terminus [26] where our unpaired cysteine is located. In chicken an unpaired cysteine is found 3 amino acids from the $\mathrm{N}$-terminus of the mature leptin protein [31]. Dridi et al. [4] substituted this cysteine with a serine and suggested that it does not alter bioactivity. However, the in vitro bioactivity assay utilized a human receptor and the activity of chicken leptin was at least one log less than ovine. In the in vivo homologous bioassay that measured accumulated food intake, the mutated leptin (serine at position 3) was more active than wildtype leptin (cysteine at position 3) although not significantly so.

The discovery of a SNP that adds an extra cysteine into the amino acid sequence of leptin, combined with a significant association to carcass fat measurements and significant variation in the level of mRNA detected between the two groups of homozygotes, suggests that we may have identified a polymorphism with a functional effect. The allele frequencies at this SNP from early and later maturing breeds also support a role in fat deposition.

\section{ACKNOWLEDGEMENTS}

We gratefully acknowledge financial support from the Natural Science and Engineering Research Council, the Saskatchewan Agriculture Development 
Fund, Agri-Food Innovation Fund and the University of Saskatchewan for a Graduate Scholarship.

We would also like to thank Roger Stone for encouraging our use of the BM1500 microsatellite in the early stages of this project and Richard Ehrhardt for providing the leptin primers for the RPA. Blair Goldade provided the technical expertise in the isolation of total RNA.

\section{REFERENCES}

[1] Barb C.R., Yan X., Azain M.J., Kraeling R.R., Rampacek G.B., Ramsay T.G., Recombinant porcine leptin reduces feed intake and stimulates growth hormone secretion in swine, Domest. Anim. Endocrinol. 15 (1998) 77-86.

[2] Blache D., Tellam R.L., Chagas L.M., Blackberry M.A., Vercoe P.E., Martin G.B., Level of nutrition affects leptin concentrations in plasma and cerebrospinal fluid in sheep, J. Endocrinol. 165 (2000) 625-637.

[3] Delavaud C., Bocquier F., Chilliard Y., Keisler D.H., Gertler A., Kann G., Plasma leptin determination in ruminants: effect of nutritional status and body fatness on plasma leptin concentration assessed by a specific RIA in sheep, J. Endocrinol. 165 (2000) 519-526.

[4] Dridi S., Raver N., Gussakovsky E.E., Derouet M., Picard M., Gertler A., Taouis M., Biological activities of recombinant chicken leptin C4S analog compared with unmodified leptins, Am. J. Physiol. Endocrinol. Metab. 279 (2000) $116-123$.

[5] Dyer C.J., Simmons J.M., Matteri R.L., Keisler D.H., cDNA cloning and tissuespecific gene expression of ovine leptin, NPY-Y1 receptor, and NPY-Y2 receptor, Domest. Anim. Endocrinol. 14 (1997) 295-303.

[6] Ehrhardt R.A., Slepetis R.M., Siegal-Willott J., Van Amburgh M.E., Bell A.W., Boisclair Y.R., Development of a specific radioimmunoas say to measure physiological changes of circulating leptin in cattle and sheep, J. Endocrinol. 166 (2000) 519-528.

[7] Fitzsimmons C.J., Schmutz S.M., Bergen R.D., McKinnon J.J., A potential association between the BM 1500 microsatellite and fat deposition in beef cattle, Mamm. Genome 9 (1998) 432-434.

[8] Fitzsimmons C.J., An investigation into leptin's role as a candidate gene for carcass fat levels in beef cattle. M.Sc. Thesis, University of Saskatchewan, Saskatoon, SK, 1999.

[9] Gallant E.M., Curtis S., Pace S.M., Dulhunty A.F., Arg615Cys substitution in pig skeletal ryanodine receptors increases activation of single channels by a segment of the skeletal DHPR II-III loop, Biophys. J. 80 (2001) 1769-1782.

[10] Gregory K.E., Cundiff L.V., Koch R.M., Dikeman M.E., Koohmaraie M., Breed effects and retained heterosis for growth, carcass, and meat traits in advanced generations of composite populations of beef cattle, J. Anim. Sci. 72 (1994) 833-850.

[11] Grone A., Weckmann W.T., Capen C.C., Rosol T.J., Canine glyceraldehyde3-phosphate dehydrogenase complementary DNA: Polymerase chain reaction 
amplification, cloning, partial sequence analysis, and use as loading control in ribonuclease protection assays, Am. J. Vet. Res. 57 (1996) 254-257.

[12] Haegeman A., van Zeveren A., Peelman L.J., New mutation in exon 2 of the bovine leptin gene, Anim. Genet. 31 (2000) 79.

[13] Halaas J.L., Gajiwala K.S., Maffei M., Cohen S.L., Chait B.T., Rabinowitz D., Lallone R.L., Burley S.K., Friedman J.M., Weight-reducing effects of the plasma protein encoded by the obese gene, Science 269 (1995) 543-546.

[14] Heaton M.P., Laegreid W.W., Beattie C.W., Smith T.P.L., Kappes S.M., Identification and genetic mapping of bovine chemokine genes expressed in epithelial cells, Mamm. Genome 10 (1999) 128-133.

[15] Henry B.A., Goding J.W., Alexander W.S., Tilbrook A.J., Canny B.J., Dunshea F., Rao A., Mansell A., Clarke I.J., Central administration of leptin to ovariectomized ewes inhibits food intake without affecting the secretion of hormones from the pituitary gland: evidence for a dissociation of effects on appetite and neuroendocrine function, Endocrinol. 140 (1999) 1175-1182.

[16] Houseknecht K.L., Baile C.A., Matteri R.L., Spurlock M.C., The Biology of leptin: A review, J. Anim. Sci. 76 (1998) 1405-1420.

[17] Inaba S., Hatakeyama H., Taniguchi N., Miyamori I., The property of a novel v2 receptor mutant in a patient with nephrogenic diabetes insipidus, J. Clin. Endocrinol. Metab. 86 (2001) 381-385.

[18] Ji S., Willis G.M., Scott R.R., Spurlock M.E., Partial cloning and expression of the bovine leptin gene, Anim. Biotech. 9 (1998) 1-14.

[19] Konfortov B.A., Licence V.E., Miller J.R., Re-sequencing DNA from a diverse panel of cattle reveals a high level of polymorphism in both intron and exon, Mamm. Genome 10 (1999) 1142-1145.

[20] Lein S., Sundvold H., Klungland H., Våge D.I., Two novel polymorphisms in the bovine obesity gene (OBS), Anim. Genet. 28 (1997) 245.

[21] Muller G., Ertl J., Gerl M., Preibisch G., Leptin impairs metabolic actions of insulin in isolated rat adipocytes, J. Biolog. Chem. 272 (1997) 10585-10593.

[22] Muoio D.M., Dohm G.L., Tapscott E.B., Coleman R.A., Leptin opposes insulin's effect on fatty acid partitioning in muscles isolated from obese ob/ob mice, Am. J. Physiol. 276 (1999) 913-921.

[23] Pomp D., Zou T., Clutter A.C., Barendse W., Mapping of leptin to bovine chromosome 4 by linkage analysis of a PCR-based polymorphism, J. Anim. Sci. 75 (1997) 1427.

[24] Raver N., Taouis M., Dridi S., Derouet M., Simon J., Robinzon B., Djiane J., Gertler A., Large-scale preparation of biologically active recombinant chicken obese protein (leptin), Protein Expression and Purification 14 (1998) 403-408.

[25] Ribba A.N., Hilbert L., Lavergne J.M., Fressinaud E., Boyer-Neumann C., The arginine-552-cysteine (R1315C) mutation within the A1 loop of von Willebrand factor induces an abnormal folding with a loss of function resulting in type $2 \mathrm{~A}$ like phenotype of von Willebrand disease: a study of 10 patients and mutated recombinant von Willebrand factor, Blood 97 (2001) 952-959.

[26] Rock F.L., Altman S.W., van Heek M., Kastelein R.A., Bazan J.F., The leptin haemopoietic cytokine fold is stabilized by an intrachain disulfide bond, Hormone Metabol. Res. 28 (1996) 649-652. 
[27] Schmutz S. M., Buchanan F.C., Winkelman-Sim D.C., Pawlyshyn V., Plante Y., McKinnon J.J., Fournier B.P., Development of the Canadian Beef Reference Herd for Gene Mapping Studies, Theriogenology 55 (2001) 963-972.

[28] Sprang S.R., Bazan J.F., Cytokine structural taxonomy and mechanisms of receptor engagement, Curr. Opin. Struct. Biol. 5 (1993) 114-121.

[29] Stone R.T., Kappes S.M., Beattie C.W., Two polymorphic microsatellites within an $18 \mathrm{~kb}$ genomic clone containing the bovine ob gene, Anim. Genet. 27 (1996) 64.

[30] Stone R.T., Kappes S.M., Beattie C.W., The bovine homologue of the obese gene maps to chromosome 4, Mammal. Genome 7 (1996) 399-400.

[31] Taouis M., Chen J-W., Davi aud C., Dupont J., Derouet M., Simon J., Cloning the chicken leptin gene, Gene 208 (1998) 239-242.

[32] Wilkins R.J., Davey H.W., A polymorphic microsatellite in the bovine leptin gene, Anim. Genet. 28 (1997) 376.

[33] Zhang Y., Proenca R., Maffei M., Barone M., Leopold L., Friedman J.M., Positional cloning of the mouse obese gene and its human homologue, Nature 372 (1994) 425-432.

To access this journal online: www.edpsciences.org 